\title{
Anesthetic Management in Premature Newborn with Huge Sacrococcygeal Teratoma: A Case Report
}

\section{Dev Sakrokoksigeal Teratomu Olan Prematür Yenidoğanın Anestezi Yönetimi: Olgu Sunumu}

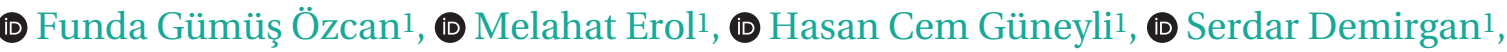 \\ (D) Mustafa Baran Yavuz¹, (D) Nurseli Toksoy², (D) Ayşin Selcan¹ \\ ${ }^{1}$ Health Science University Turkey, Bağcllar Training and Research Hospital, Clinic of Anesthesiology, İstanbul, Turkey \\ ${ }^{2}$ Health Science University Turkey, Bağcllar Training and Research Hospital, Clinic of Pediatric Surgery, İstanbul, Turkey
}

Abstract

Sacrococcygeal teratomas are the most common congenital tumors in newborns. The primary treatment is early surgical resection. However, the risks of surgical procedures and tumor morphology, as well as the challenges of premature newborns, make the anesthetic management distinguished. In this case report, we present anesthesia management of $3.420 \mathrm{gr}$ newborn on the postnatal $3^{\text {rd }}$ day, who was born by caesarean delivery with $176 \times 130 \times 130 \mathrm{~mm}$ huge sacrococcygeal teratoma at 32 weeks of gestation

Keywords: Anesthesia, premature newborn, sacrococcygeal teratoma

\section{Öz}

\begin{abstract}
Sakrokoksigeal teratomlar yenidoğanlarda en sık görülen konjenital tümörlerdir. Birincil tedavisi erken cerrahi rezeksiyondur. Bununla birlikte, cerrahi prosedür, tümör morfolojisi ve prematür yenidoğan ile ilişkili zorluklar anestezi yönetimini karmaşık hale getirir. Bu olgu sunumunda 3,420 gr ağırlığında, 32. gestasyon haftasında sezaryen ile doğurtulmuş, 176x130x130 mm boyutlarında dev sakrokoksigeal teratomu olan 3 günlü yenidoğanın anestezi yönetimini sunduk.
\end{abstract}

Anahtar kelimeler: Anestezi, premature yenidoğan, sakrokoksigeal teratom

\section{Introduction}

Sacrococcygeal teratoma (SCT) is the most common congenital tumors in newborns (1). The primary treatment is the total excision of the tumor as early as possible after birth $(2,3)$. During the excision of massive tumors with high vascularity, the intraoperative phase becomes complicated due to fast and massive hemorrhage, massive transfusion, hypovolemia, hyperpotassemia, coagulopathy, acidosis, and hypothermia $(1,4,5)$.
In this case report, we presented the anesthetic management for the excision of a huge SCT of 176x130x130 mm on the postnatal $3^{\text {rd day. }}$

\section{Case Report}

A female newborn who was diagnosed with a mass in the gluteus as shown by the prenatal ultrasound and delivered as 3.420 gr at 32 weeks of gestation by emergency caesarean section was included in the study. The mass was thought

Address for Correspondence: Funda Gümüş Özcan, Health Science University Turkey, Bağcılar Training and Research Hospital, Clinic of Anesthesiology, İstanbul, Turkey

E-mail: fgumus@hotmail.com ORCID ID: orcid.org/0000-0003-3264-4356 Received: 20.07.2020 Accepted: 19.08.2020

Cite this article as: Gümüş Özcan F, Erol M, Güneyli HC, Demirgan S, Yavuz MB, Toksoy N, Selcan A. Anesthetic Management in Premature Newborn with Huge Sacrococcygeal Teratoma: A Case Report. Bagcilar Med Bull 2020;5(3):144-147

${ }^{\odot}$ Copyright 2020 by the Health Sciences University Turkey, Bagcilar Training and Research Hospital Bagcilar Medical Bulletin published by Galenos Publishing House. 
to be a SCT (Figure 1), thus, it was decided to perform an operation.

The newborn was assessed in intensive care preoperatively. Physical examination results were normal but SCT of approximately 20x15 $\mathrm{cm}$ starting from the perineum, involving the rectum and extending behind the sacrum

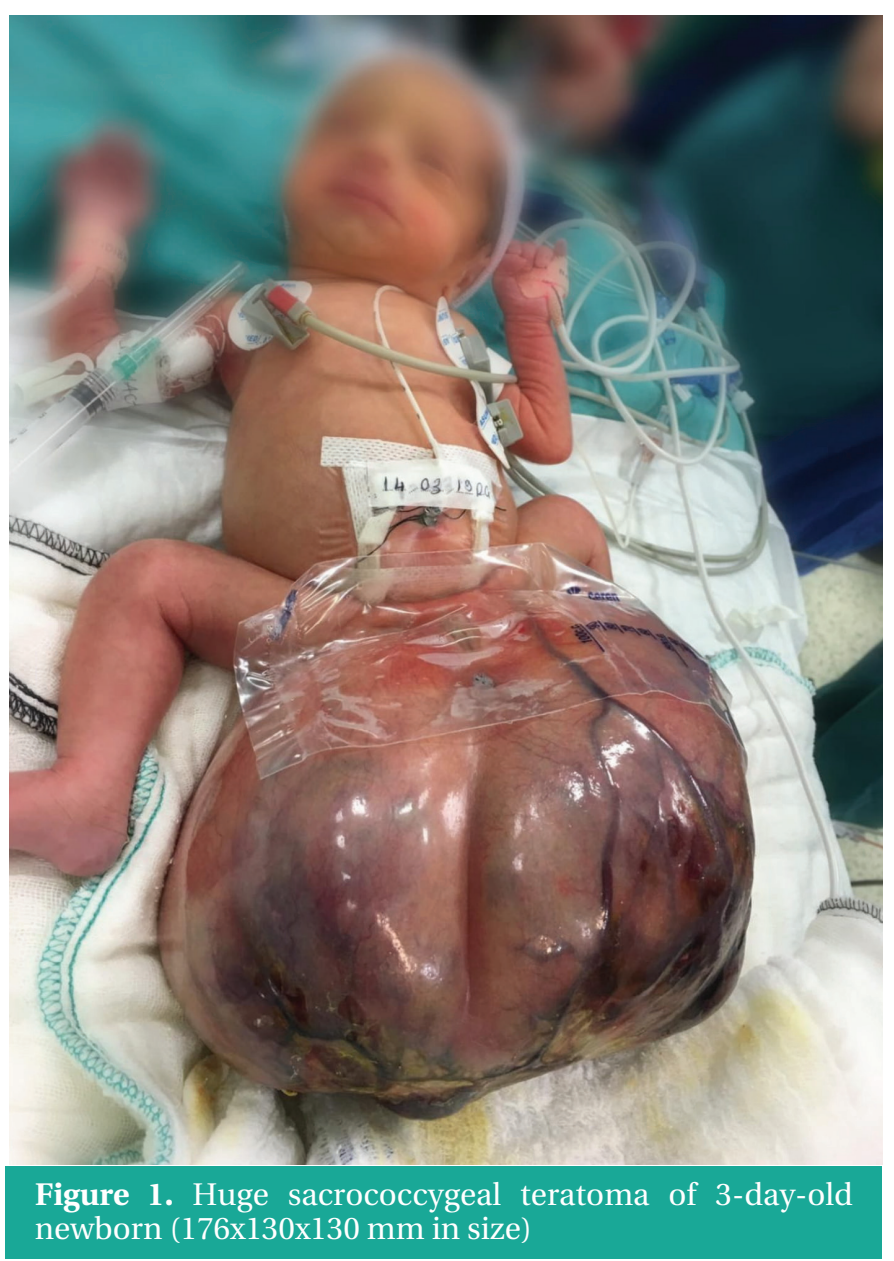

covered with highly vascular and regional erosions was observed. The magnetic resonance imaging showed that the mass was $135 \mathrm{~mm}$ on the cranio-caudal plane, 176x130 $\mathrm{mm}$ on the axial plane, smoothly contoured, lobulated in some regions, solid and multicystic, filling the presacral and precoccygeal region, with no extension into the abdomen. Cranial and echocardiographic images were considered to be normal, and hemoglobin was $15.7 \mathrm{gr} / \mathrm{dL}^{-1}$, hematocrit (Hct) was $46.1 \%$, platelet (Plt) was $158,000 \mu \mathrm{L}^{-1}$, ctivated partial thromboplastin time was $29.8 \mathrm{sec}$, prothrombin time was $15 \mathrm{sec}$, international normalized ratio was 1.3 , fibrinogen was $121 \mathrm{mg} / \mathrm{dL}$, and alpha-fetoprotein (AFP) was $>54,000$. Erythrocyte suspension (ES), fresh whole blood (WB), fresh frozen plasma (FFP) and Plt suspension were prepared preoperatively. On the postnatal $3^{\text {rd }}$ day, the operating room was heated to $25^{\circ} \mathrm{C}$, infusion pumps and vasoactive drugs were prepared before anesthesia induction. Electrocardiogram, oxygen saturation and non-invasive BP were monitored. For venous access, preoperatively placed umbilical and right brachial central venous catheters were used. The induction was done with $1 \mu \mathrm{g} \mathrm{kg}^{-1}$ of fentanyl, $0.6 \mathrm{mg} \mathrm{kg}^{-1}$ of rocuronium, $8 \%$ sevoflurane and $50-50 \% \mathrm{O}_{2}$-medical air mixture, and the newborn was intubated with number 3 endotracheal tube. The anesthesia was maintained with $2-2.5 \%$ sevoflurane in $50-50 \% \mathrm{O}_{2}$-medica-air and ventilated manually throughout the operation. The fluid infusion was done using Ringer's lactate and at $0.9 \mathrm{NaCl} 50 \mathrm{~mL} /$ hour. Invasive arterial pressure was monitored in the left radial artery after intubation, and nasopharyngeal temperature, urine flow and arterial blood gas (ABG) (Table 1) were monitored. The newborn was put into prone position. As the mass was huge and highly vascular, erythrocyte transfusion was started at

Table 1. Arterial blood gas analyses of the patient in preoperative, intraoperative and postoperative period

\begin{tabular}{|c|c|c|c|c|}
\hline & Preoperative & Intraoperative & Postoperative & ICU period \\
\hline $\mathrm{pH}$ & 7.28 & 7.22 & 7.41 & 7.45 \\
\hline $\mathrm{PaCO}_{2}(\mathrm{mmHg})$ & 48 & 42 & 26 & 27 \\
\hline Het (\%) & 46.7 & 30 & 22.1 & 27 \\
\hline $\mathrm{Hbg}(\mathrm{gr} / \mathrm{dL})$ & 15.3 & 10 & 7.1 & 9 \\
\hline $\mathrm{K}^{+}(\mathrm{mmol} / \mathrm{L})$ & 3.5 & 3.7 & 4.2 & 3.5 \\
\hline Glucose (mg/dL) & 78 & 377 & 275 & 152 \\
\hline Lactate (mmol/L) & 2.2 & 2.7 & 7 & 9.9 \\
\hline $\mathrm{BE}(\mathrm{mmol} / \mathrm{L})$ & $-4,8$ & -9 & -4 & 9 \\
\hline
\end{tabular}

BE: Base excess, $\mathrm{Ca}^{2+}$ : Calcium, $\mathrm{K}^{+}$: Potassium, $\mathrm{Na}^{+}$: Sodium, $\mathrm{Hbg}$ : Hemoglobin, Hct: Hematocrit, ICU: Intensive care unit, PaCO ${ }_{2}$ Partial pressure of carbon dioxide, PaO ${ }_{2}$ : Partial pressure of oxygen 
the same time with the surgical excision. Whereas the heart rate (HR) was $135 \mathrm{bpm}$ and the blood pressure (BP) was $85 / 60 \mathrm{~mm} / \mathrm{Hg}$ at the beginning of the operation, sudden bradycardia (40 bpm), hypotension $(20 / 15 \mathrm{~mm} / \mathrm{Hg})$ and circulatory collapse developed as soon as having started to excise the tumor in 30 minutes in the operation. Twenty $\mu \mathrm{g}$ of adrenalin ( 3 intermittent doses) and $20 \mu \mathrm{g} / \mathrm{kg}$ of atropine were administered, and $10 \mu \mathrm{g} / \mathrm{kg} / \mathrm{min}$ of dopamine and $10 \mu \mathrm{g} / \mathrm{kg} / \mathrm{min}$ of noradrenaline infusions were started, concurrently transfusion was continued with manual WB and FFP infusions. The patient had no hypothermia and her temperature was $36{ }^{\circ} \mathrm{C}$ during surgery. Hemodynamic stabilization was attained approximately 5 minutes after the circulatory collapse (HR: $120 \mathrm{bpm}, \mathrm{BP}: 80 / 50 \mathrm{~mm} / \mathrm{Hg}$ ). Acidosis, hypocalcemia and hyperglycemia were detected in the ABG analyses. The transfusion was maintained since Hct dropped from $46 \%$ to $30 \%$ due to the hemorrhage continuing on the surface of the mass. The operation was completed in 225 minutes with the newborn in the prone position and the mass excised weighed as $1.450 \mathrm{gr}$. Throughout the operation, total of $100 \mathrm{~mL}$ of ES, $235 \mathrm{~mL}$ of WB, $80 \mathrm{~mL}$ of FFP, and $600 \mathrm{~mL}$ of crystalloid fluid infusion were administered. At the end of the operation, the newborn was transferred to the neonatal intensive care unit (ICU) in an intubated state and without inotrope infusion. During ICU follow up, the patient also did not need inotropic agent. The mean urine output of the patient was about 5.05 $\mathrm{cc} / \mathrm{h}$ in ICU. Lactate level of the patient was $2 \mathrm{mmol} / \mathrm{L}$ at the discharge from the ICU. Weighed as 1.410 gr in the early postoperative phase in the intensive care, the newborn was extubated on the postoperative $1^{\text {st }}$ day. Weighed as $3.075 \mathrm{gr}$ on day 65 , her AFP was measured as $397 \mathrm{u} / \mathrm{mL}$ and she was discharged from the hospital.

\section{Discussion}

SCTs are surgically removed in total, the survival rate is $77 \%$ $94 \%$ (1). Timing of the surgery is recommended to be as soon as possible immediately after birth because any delay may result in the development of coagulopathy $(1,4,5)$. In case of huge and highly vascular SCTs, it may result in massive hemorrhage complication. During the dissection of SCT, massive hemorrhage is the biggest cause of intraoperative mortality $(1,4-6)$. The rate of hemorrhagic mortality was reported as $3.8 \%$ (6). Therefore, for patients with huge SCT, it is recommended to keep blood products available to allow for commencing transfusion as soon as the surgery begins. Also, large intravenous routes and invasive hemodynamic monitoring are recommended (1,4-7). In these operations, another problem is hypothermia, which may develop during the operation due to loss of heat from a large tumor site in spite of all the measures taken $(1,4-6)$.

There are studies that report more stable SCT cases requiring less blood transfusion. Silay et al. (8) experienced short-term hemodynamic instability 5 minutes after the excision of a mass of $980 \mathrm{~g}$ from a 40-week-old baby. They ensured hemodynamic stabilization with $100 \mathrm{~mL}$ of blood transfusion and volume and inotrope infusion (8). During the excision of a mass of 850 gr from a 38-week-old baby weighting $4.460 \mathrm{gr}$, Akin et al. (9) completed the operation without blood transfusion. Unlike these cases, our case was a premature, weighting $3.420 \mathrm{gr}$ and the mass excised weighed $1.450 \mathrm{gr}$; in other words, the mass was too big considering the weight of the baby and highly vascular. We think that the sudden hemodynamic compromise and the need for massive blood transfusion in our case are also attributable to these causes.

\section{Conclusion}

The risk of morbidity and mortality is high while operating on particularly large SCTs with high vascularity in premature newborns. The primary cause of mortality is the massive hemorrhages from the surgical and intratumoral site. Therefore, in such patients, blood products must be prepared preoperatively, large intravenous routes must be placed, and invasive hemodynamic monitoring must be done throughout the operation.

\section{Ethics}

Informed Consent: Consent form was taken from patients.

Peer-review: Externally peer-reviewed.

\section{Authorship Contributions}

Concept: F.G.Ö., M.E., H.C.G., S.D., M.B.Y., N.T., A.S., Design: F.G.Ö., M.E., H.C.G., S.D., M.B.Y., N.T., A.S., Data Collection or Processing: F.G.Ö., M.E., H.C.G., S.D., M.B.Y., N.T., A.S., Analysis or Interpretation: F.G.Ö., M.E., H.C.G., S.D., M.B.Y., N.T., A.S., Writing: F.G.Ö., M.E., H.C.G., S.D., M.B.Y., N.T., A.S.

Conflict of Interest: The authors declare that there is no conflict of interest with regard to this manuscript.

Financial Disclosure: No financial support was received from a person or a company for writing this case report.

\section{References}

1. Abraham E, Parray T, Ghafoor A. Complications with massive sacrococcygeal tumor resection on a premature neonate. J Anesth 2010;24(6):951-954. 
2. HuddartSN, Mann JR, Robinson K, Raafat F, Imeson J, Gornall P, et al. Sacrococcygeal teratomas: the UK Children's Cancer Study Group'sexperience. I. Neonatal. Pediatr Surg Int 2003;19(1-2):4751.

3. Wakhlu A, Misra S, TandonRK, Wakhlu AK. Sacrococcygeal teratoma. Pediatr Surg Int 2002;18:384-387.

4. Isserman RS, Nelson O, Tran MK, Cai L, Polansky M, Rosenbloom JM, Goebel TK, et al. Risk factors for perioperative mortality and transfusion in sacrococcygeal teratoma resections. Paediatr Anaesth 2017;27(7):726-732.

5. Kim JW, Gwak M, Park JY, Kim HJ, Lee YM. Cardiac arrest during excision of a huge sacrococcygeal teratoma- A report of two cases. Korean J Anesthesiol 2012;63(1):80-84.
6. Kremer ME, Wellens LM, Derikx JP, van Baren R, Heij HA, Wijnen MHWA, et al. Hemorrhage is the most common cause of neonatal mortality in patients with sacrococcygeal teratoma. J Pediatr Surg 2016;51(11):1826-1829.

7. Singh A, Jain M, Majumdar M, Jain BB. Anesthetic Management of Sacrococcygeal Teratoma-A Case Report. Ann Int Med Den Res 2018;4(4):AN01-3.

8. Silay E, Coşkuner İ, Yıldız H, Yardımcı C, Özkan KU, Davutoğlu M. The Importance of the Management of Anaesthesia During Surgery for Sacrococcygeal Teratoma in the Newborn. Turk J Anaesth Reanim 2012;40(6):332-334.

9. Akin M, Keskin G, Şenaylı Y. Journal of Anesthesia- JARSS 2017;25(2):96-100. 